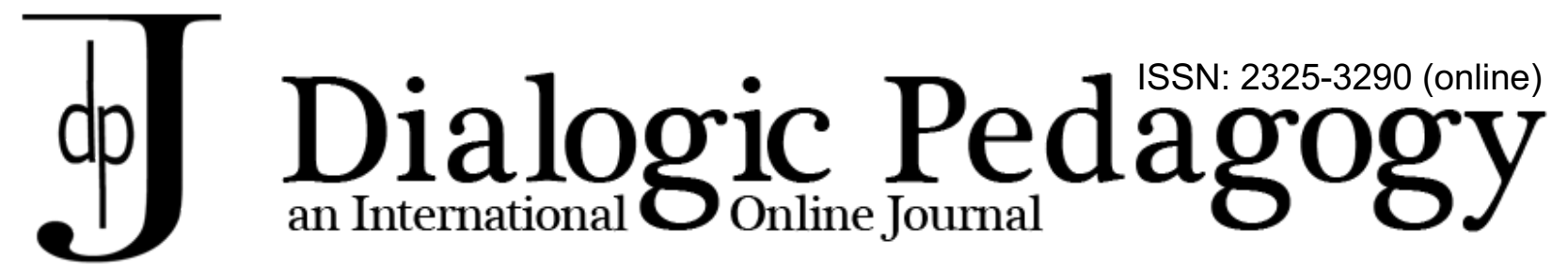

\title{
Dialogic functions of repair by lexical synonymy in the process of writing and rewriting of an opinion article
}
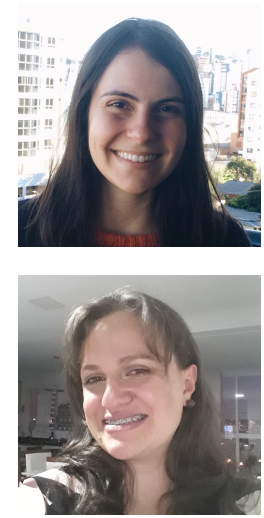

\section{Gabriela Aiolfi}

Federal University of Technology of Paraná (UTFPR), Brazil

\section{Letícia Lemos Gritti}

Federal University of Technology of Paraná (UTFPR), Brazil

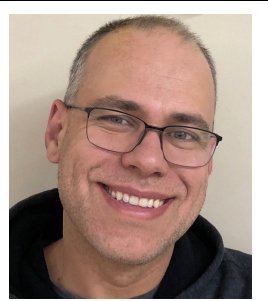

Anselmo Lima

Federal University of Technology of Paraná (UTFPR), Brazil

\begin{abstract}
This article presents a study that aims to identify and analyze dialogic functions of repair by lexical synonymy in the process of writing and rewriting of an opinion article. The data were collected in the Research Laboratory entitled 'Workshop of Reading, Writing and Rewriting of Opinion Articles', an activity of the Research Group UTFPR-CNPq LAD'Humano, in 2015. The opinion articles were written by first term undergraduate students of the Letters Teacher Certification Program in Portuguese-English of the Federal University of Technology of Paraná, Brazil, Pato Branco Campus. The writing of the texts was recorded by the software AutoScreen Recorder and Inputlog. The analyses are mainly based on Bakhtin, Volosinov, and Vygotsky and show that repair by lexical synonymy has the dialogic functions of addressing the target audience of the text, of textual adjustment, of giving the desired content to discourse and of acting in the process of construction of the writer's image. As "the meaning of the word is completely determined by its context" (BAKHTIN/VOLOCHÍNOV, 2014, p.109), it is the verbal and extraverbal context of a certain word choice that will contribute or not to building the meaning intended by the writer, and that is why synonymy study in the process of writing is important.
\end{abstract}

Gabriela Aiolfi is a master's student at Universidade Tecnológica Federal do Paraná (Federal University of Technology (UTF) - Paraná State, Brazil). She develops her work in the Graduate Program in Linguistics and Literature (PPGL - UTFPR) under the guidance of Dr. Anselmo Lima. Her work focuses on the study of the process of writing and rewriting of a text in a computational environment, mainly on the phenomena that constitute such process, deeply influenced by Bakhtin, Vigotsky, Voloshinov and studies from Genetic Criticism. She holds a teaching degree in Portuguese and English Languages and Literature from the Federal University of Technology - Paraná State, Pato Branco Campus. She held a scientific initiation scholarship from the Institutional Scientific Initiation Scholarship Program (PIBIC - CNPq) from 2016 to 2018 and is part of the CNPq research group Linguagem, Atividade e Desenvolvimento Humano (LAD'Humano - Language, Activity and Human Development).

Anselmo Lima is a tenured Professor of Educational Linguistics at Universidade Tecnológica Federal do Paraná - UTFPR (Federal University of Technology of Parana State, Brazil). PhD in Applied Linguistics and 
Language Studies from Pontifícia Universidade Católica de São Paulo - PUC-SP (Pontifical Catholic University of Sao Paulo, Brazil); PhD internship in Occupational Psychology at Conservatoire National des Arts et Métiers de Paris - CNAM (National Conservatory of Arts and Trades of Paris, France) and PostDoc in the College of Education and Human Development of the University of Delaware, USA. He is the author of "Teacher Education \& Teacher Health": www.formacaoesaudedoprofessor.com

Leticia Lemos Gritti is a tenured Professor of Linguistics and Portuguese Language at the Department of Letters, of the Federal University of Technology (UTF) - Paraná State, where she teaches Portuguese Language and Formal Linguistics at an undergraduate Teaching degree course in Portuguese and English Languages and Literature, in which she was in a course coordination between 2015 and 2016. She also works as Professor and Researcher in the Graduate Program in Linguistics and Literature of (PPGL UTFPR). The author holds a PhD in Linguistics from the Federal University of Santa Catarina, where she defended her doctoral thesis in the area of Formal Semantics. From September 2010 to July 2011, she did a sandwich internship at Université Paris Diderot (Paris VII), Structures Formelles du Language, in Paris, through the Capes-Cofecub Project, a Brazil-France cooperation.

\section{Acknowledgements:}

Special thanks to CNPq, for research funding; to UTFPR, for scholarships that helped undergraduate students participate in this project; to Doctor Mirian Ruffini, for her fine proofreading of our text; to our managing hidden editors, for their invaluable help with revisions.

$\cos \cos 80$

\section{Introduction}

When writing an opinion article, the writer's choice of words is extremely important. Among other things it is responsible for the targeted audience's acceptance or rejection of his or her position. When making a word choice, the person who writes can displace a word or use an inaccurate term that would not be helpful in the task of convincing the reader. To solve this problem, the writer can repair his or her text by means of replacement of the "problematic" word for a synonymous term.

Understanding what happens in this phenomenon of the exchange of words can be very useful for teaching and learning the textual production of an opinion article. In addition, thoroughly analyzing this process can bring advances in the area of linguistics and applied studies.

We seek, in this paper, to identify and analyze the dialogic functions of repair by lexical synonymy ${ }^{1}$ in the process of production of an opinion article. Given this objective, our major research question can be specifically stated as follows: what are the dialogic functions of repair by lexical synonymy in the process of writing and rewriting of an opinion article?

Others have already studied lexical synonymy with different objectives. For instance, Spáčilová (2009) carried out a study about some synonymous words and their use according to their semantic category and their meanings. Stanojević (2009) wrote about cognitive synonymy, concluding that cognitive synonyms have the same sense in common, even regarding the different registers, styles or dialects they belong to. Silva (2015) studied lexical synonymy in concrete cases, taking social factors in consideration

\footnotetext{
${ }^{1}$ In lexical synonymy, according to llari and Geraldi (2006), there are two words that contribute to the same meaning of the sentence. "Repair" is a term that means "self-correction" and lexical synonymy is a kind of repair. This article aims to study dialogic functions of this repair.
} 
when analyzing changes of words meaning, following elements from Cognitive Sociolinguistics. Al-hindawi and Alkhazaali (2014) studied synonymy as a stylistic marker and as an element related to the themes of William Wordsworth's poetry.

The process of repair has been examined by other studies as well, like the one carried out by Schegloff, Jefferson and Sacks (1977), who highlighted repair as a phenomenon in which "linguistics and sociology meet", being the "self-righting mechanism for the organization of language use in social interaction" (p.381). Schegloff (1979) shows that repair has an important role in the sequential organization, the syntax, of conversations. Clark and Andersen (1979) studied repair in the process of children's language acquisition, concluding that spontaneous repairs close the gap between children's language knowledge from input received and from their own language production.

All these works analyzed data from conversational sources. We do not know of other investigations that deal specifically with repair by lexical synonymy in written text the way we propose to do in this article. Maybe they do not exist or are hard to find. This seems to indicate that this field of study has not yet been totally explored.

Focusing on the role of words in written discourse, this study therefore addresses some of the gaps in the existing literature of lexical synonymy and repair. And it also examines written data from the point of view of its production process. This last fact establishes the major difference between this paper and the ones mentioned above, which focused their attention exclusively on oral texts (conversations).

Our work is organized in three major sections. In section I, just below, we present our theoretical basis, which is developed in six subsections, as follows: 1) text and speech genres; 2) text as process; 3 ) synonymy; 4) argumentation and repair by lexical synonymy; 5) opinion articles, and 6) a discussion on the position of the writer as his or her own first reader.

In section II, we present our methodology, which, in its turn, is developed in two subsections: 1) authentic data production for analysis, and 2) computerized method: the use of AutoScreen Recorder and Inputlog.

In section III, we present and discuss our findings in six subsections, each of which approaches a specific process of word substitution by synonymy: 1) pessoas ou jovens? (people or youngsters?); 2) câncer ou tumor? (cancer or tumor?); 3) cobrar, exigir ou fazer com que? (to require, to demand or to make somebody have something done?); 4) governo ou poder público? (government or public authorities?); 5) acidentes ou tragédias? (accidents or tragedies?); and 6) pois ou visto que? (because or seeing that?).

Our work is concluded with some final remarks and a list of references.

\section{Theoretical basis}

To identify and analyze the process of repair by lexical synonymy in the writing and rewriting phases of an opinion article, we have used theoretical concepts from Linguistics and Psychology, which are presented in the following subsections. 


\section{Text and speech genres}

Wachowicz (2012, p.22) states that "text is discourse" ${ }^{2}$ (author's highlight). For this reason, when we here talk about text, we do not only seek to strictly analyze its linguistic aspects, but also how these aspects act in the social environment in which they belong: "it means to think about the historical ideology that constituted it"3 (WACHOWICZ, 2012, p.23). This author's statement is compatible with the concept of speech genres (BAKHTIN, 2011), adopted in our research. Text, which is therefore also a form of speech, is here understood as utterance, that is, a unit of communication. Each field of human activity uses certain relatively stable types of utterances, which are called speech genres.

Bakhtin (2011, p.263) emphasizes the heterogeneity of speech genres and classifies them into two categories: the primary genres and the secondary genres. The first classification involves more "simple" genres, the daily utilized ones. The second considers the more intricately organized ones, which involve, mostly, written texts. That which characterizes genres are their constitutive elements, which are inseparable among themselves: interlocutive relationship, compositional construction, thematic content and style.

The objective of working with the notion of genre is not merely the analysis of linguistic terms that define the text, but to analyze the text in its socio-interactive flow of communication and how the linguistic elements act in this flow.

\section{Text as process}

According to the concept presented in the previous subsection, text imbued with a particular historically expressed ideology. It can be thought of as a historical diachronic process. In our study, the idea of process refers to a perspective that faces text not simply as a product of writing activity, as an object of linguistic aspects analysis. Our approach seeks to explore the very process of writing, i.e. the flow of written production, with all the writer's hesitations that are not visible in the final text delivered to the reader. Therefore, we perceive text as a process, not as a mere product of communication.

Vigotski (2007, p.63), working within developmental psychology, says that the analysis of a process "requires a dynamic exposition of the main constitutive points of the history of the processes"4. The repairs made by the writer in the process of writing, are possibly also important constitutive points of this process. This is why we chose to analyze the functions of repairs in the development of the writer's production as one of the several constituents of text. As it will be seen in our methodology section, repair by lexical synonymy was chosen for analysis in particular because of its high frequency of occurrence, which stood out among other textual operations. The phenomenon of (text) repair is constituted by writing a word or some words that are then erased and replaced. This phenomenon could only be perceived by following the writer's process of writing. We thus do not seek to study text only for what it is, but also for what it could have become (LIMA, 2014, p.39).

The conception of text as a product makes sure that a writing does not leave clues of the process of planning, presenting itself as a completed and complex whole (RODRIGUES, 2010, p.36). It is therefore a feature of writing not to "provide clues, apparent marks concerning the process of its creation. It usually hides such processes from the reader and it shows only the finished product" 5 (CHAFE, 1985 apud RODRIGUES, 2010, p.32-33). This point of view excludes, in part, the fact that there are "trepidations" in

\footnotetext{
${ }^{2}$ Original: "texto é discurso".

${ }^{3}$ Original: "significa pensar na ideologia histórica que o constituiu".

${ }^{4}$ Original: "requer uma exposição dinâmica dos principais pontos constituintes da história dos processos".

${ }^{5}$ Original: "não fornecer pistas, marcas aparentes a respeito do processo de criação. Geralmente ela esconde tais processos do leitor e mostra apenas o produto acabado".
} 
written production and that the final product does not correspond to the first attempt of writing, to the first outline, an initial creative moment.

Salles (2008), a researcher of the Genetic Criticism ${ }^{6}$ field, studies the creative process of literature, which does not pull away from the procedural perspective of our linguistic focus. When this author says that "the creative act is the result of a process"7 (SALLES, 2008, p.25), it is evident that the marks of the creative flow are present in the written textual production. Text takes shape in its creative flow, and all the hesitations of the writer are part of it. In this way, the work delivered to the audience and all the operations involved in its construction are a single object. In other words, the final product is not detached from the process of its production. On the contrary, its production is a constituent and an important part of the text, but it cannot be considered the only single part of the whole (BIASI, 2012; SILVA, 2010; SALLES, 2008; HAY, 1993; GRÉSILLON and LEBRAVE, 1983).

\section{Synonymy}

From a historical-ideological perspective, a text is always addressed to someone. Bakhtin/Volochínov (2014, p.116) claims that the word is always addressed to an interlocutor. This statement emphasizes the importance of the interlocutive relationship in the discussion about the chosen word. Which word (among several possible ones) will have the desired impact on the reader? When it is selected to integrate in an utterance, a word becomes an ideological sign. The ideological sign will reflect (and it will also refract) the writer's position (BAKHTIN/VOLOCHÍNOV, 2014, p.99). As "the meaning of the word is completely determined by its context"8 (BAKHTIN/VOLOCHÍNOV, 2014, p.109), it is the verbal and extraverbal context of a certain word choice that will contribute or not to building the meaning intended by the writer, and that is why synonymy study in the process of writing is important.

It is also important to remember that a text is a part of a social context, and each context provides "certain grammatical choices to be made by the individuals"9 (WACHOWICZ, 2012, p.23). The writer of an opinion article, with the purpose of convincing his or her readers, seeks for linguistic elements that respond to his or her objectives (WACHOWICZ, 2012, p.23), which produce the desired meaning.

With this in mind, it is important to define what synonymy is. Ilari and Geraldi (2006, p.43) broadly define synonymy on the lexical level as "the identity of meaning"10. However, the authors bring some observations about this definition. The first of them is that the synonymous terms not only allude to the same object, but also allude to the same meaning (ILARI; GERALDI, 2006, p.44). The identity of meaning discussed by the authors is that words must bring the same contribution to the meaning of the sentence, in any application, to be considered synonyms. Nevertheless, it is recognized by them that the use of a synonymous term in any situation will not always result in the desired effect, because synonymy is directly connected to its context of use (ILARI; GERALDI, 2006, p.44-46).

Once the meaning of a word depends on the context in which it occurs, it is impossible to claim that it is a case of perfect synonyms, exactly because they are not "interchangeable in all the contexts"11 (PIETROFORTE; LOPES, 2008, p.126). Therefore, when they can be used in the same context, they will have different discursive impacts (PIETROFORTE; LOPES, 2008, p.126).

\footnotetext{
${ }^{6}$ Genetic criticism studies the genesis of text, mainly the literary creation process and its traces of writing.

${ }^{7}$ Original: "o ato criador é resultado de um processo".

${ }^{8}$ Original: "o sentido da palavra é totalmente determinado por seu contexto".

${ }^{9}$ Original: "determinadas escolhas gramaticais pelos indivíduos".

${ }^{10}$ Original: "identidade de significação".

${ }^{11}$ Original: "intercambiáveis em todos os contextos".
} 
According to the context of a word choice, the load of meaning of one will be different from that of the other, because "some type of specialization, of meaning or use"12 always happens (ILARI; GERALDI, 2006, p.47). Concerning this, the authors talk about the choice of a synonymous term by saying that,

presumably equivalent, synonymous expressions are, even so, expressions among which the interlocutors choose: choice is, in this case, a "search for the exact word"[...], which shows that two expressions are not equally appropriate to the target purposes ${ }^{13}$ (ILARI; GERALDI, 2006, p.47, highlighted by the authors)

We assume that the target purpose of repair by synonymy in an argumentative text is the provocation of certain reactions in the reader by the word use in the context of discussion, as the data show later. Thus, the choice of synonymous expressions is almost never randomly made.

\section{Argumentation and repair by lexical synonymy}

Perelman and Olbrechts-Tyteca (2005, p.04) define the object of argumentation theory as "discursive techniques that allow to induce and enhance the adherence of minds to the theses presented for their assent" (highlighted by the authors) ${ }^{14}$. We think that a search for a synonym can be seen as one of these techniques.

The expression provided by a word only exists in the "process of its living use in a concrete utterance"15 (BAKHTIN, 2011, p.292) and an "absolutely neutral utterance is impossible"16 (BAKHTIN, 2011, p.289). The ideological sign is not taken from a neutral language, it is taken from other utterances and it is repeated and recreated to suit the purpose of the utterance under construction. In the context of argumentation, words serve the ideology defended by the writer.

A word or an ideological sign is the bearer of a point of view to be defended or attacked, and the choice of a word will be influenced by this fact. Vigotski (1996, p.67) conceptualizes human behavior as being "a system of triumphant reactions"17. Articulating this concept with the process of repair by lexical synonymy, a chosen synonym among several contestant terms is a triumphant one. All the available words compete among themselves and, in the case of argumentation, the argumentative potential of a word in a certain context can be decisive for its choice to be made.

Vigotski (1996, p.69) affirms that behavior which is realized is a tiny portionof the universe of all possible behaviors because "human beings are every minute full of unrealized possibilities" ${ }^{18}$. Relating this idea to repair by lexical synonymy, we can say that a chosen synonym, the term that triumphs over the others, is just one of the several that could be used. However, some unrealized possibilities leave marks in the process of writing because they compete for space in the subject's speech, who hesitates between the choice of one possibility over that of another.

\footnotetext{
${ }^{12}$ Original: "algum tipo de especialização, de sentido ou de uso".

${ }^{13}$ Original: "[...] presumidamente equivalentes, as expressões sinônimas são, ainda assim, expressões entre as quais os locutores escolhem: a escolha é, no caso, uma "procura da palavra exata" [...], a mostrar que duas expressões não são igualmente adequadas aos fins visados [...]".

${ }^{14}$ Original: "técnicas discursivas que permitem provocar ou aumentar a adesão dos espíritos às teses que se lhes apresentam ao assentimento" (grifos dos autores).

${ }^{15}$ Original: "processo do seu emprego vivo em um enunciado concreto".

${ }^{16}$ Original: "enunciado absolutamente neutro é impossível".

17 Original: "um sistema de reações triunfantes".

18 Original: "o comportamento que se realizou é uma parte insignificante dos comportamentos possíveis. Cada minuto do homem está cheio de possibilidades não realizadas".
} 
The writer, among several conflicting possibilities of lexical choices, seeks for the one that accomplishes his or her speech, the one that is more appropriate for the genre (LIMA, 2016a, p.29). However, this choice is neither immediate nor easy. The writer's choice attempts can be understood as inarticulateness in the 'opinion article' genre. Lima (2016a, p.24) conceptualizes lack of mastery of a genre not just as lack of capacity to be articulate in the genre, but also as a specific activity through which the subject develops from genre inability to genre ability. In other words, he or she develops from lack of genre mastery to genre mastery. Lima also emphasizes that, when performing this activity, the subject makes efforts to comply with the social specificities of the genre (LIMA, 2016a, p.24). By means of the process analysis, we notice that hesitations by the writer, when choosing a word, is evidence of social and dialogical influence, since, at times, the subject pauses his or her writing, standing speechless while facing a certain disturbing communicative situation (LIMA, 2016a p.27).

\section{Opinion articles}

The "opinion article" genre "draws on argumentation to analyze, evaluate and respond to a controversial issue"19 (BOFF; KÖCHE; MARINELLO, 2009, p.03). The subject approached, most of the time, encompasses social issues that raise hot discussions. The subject assumes a defensive position regarding his or her opinion and, through argumentation, seeks to convince his or her reader to adhere to the defended idea (BOFF; KÖCHE; MARINELLO, 2009, p.03).

An opinion article is an utterance because it works as a form of concrete communication and it has "absolutely precise limits"20 (BAKHTIN, 2011, p.275). The limits of this utterance are defined by the alternation of the subjects of discourse, which establishes an absolute beginning and an absolute end: the previous utterances - which it responds to - and the subsequent ones - that will respond to it. Bakhtin (2011, p.275) says that the utterance limit is determined by the responsive comprehension of the other. Therefore, when the speaker has said all he or she had to say about a topic (relative semantic-objectual finiteness of the thematic content) he or she gives the floor so the other(s) can respond.

Bakhtin (2011, p.276) also emphasizes that the configuration of secondary genres is differentiated, since whoever writes also responds, makes objections and refutes his or her own questions. This may correspond to repairs of the written text because the writer is his or her first reader (as we are going to emphasize in the following subsection). Besides, a text whose writer assumes is finished is not finished at all. It is not finished because it is waiting for active responsive comprehensions coming from the readers.

An utterance, that is, an opinion article produced by a writer, is not the only existing text produced about a specific topic or object of debate, which, according to Bakhtin (2011, p.281), is inexhaustible. In other words, it can be approached in infinite ways, from several different points of view. In an opinion article, only one aspect of a certain topic is usually approached, and it can only be relatively exhausted. That is because the impression over readers can generate several interpretations, returning to the inexhaustible character of the topic.

\section{The position of the writer as his or her own first reader}

Grésillon and Lebrave (1983, p.09) stress the importance of the role of the writer as his or her first reader. Although they give emphasis to this topic in the literary sphere, the same happens in a non-literary production. A writer, as his or her first reader, has

\footnotetext{
${ }^{19}$ Original: " se vale da argumentação para analisar, avaliar e responder a uma questão controversa".

${ }^{20}$ Original: "limites absolutamente precisos".
} 
different powers from those of an ordinary reader: a writer is a reader who is, at the same time, the one who writes, the one who reads, who comments, who rewrites, etc. Lebrave says that writing and reading are inseparably intricate in the production of a text. The author is more of a reader than a writer. It is always possible to correct, to modify, to cancel, to enrich the utterance that is already produced. These corrections are effects more related to reading than to writing itself (SALLES, 2008, p.109-110) ${ }^{21}$

When a writer reads his or her own work and becomes his or her first interlocutor, he or she is to a certain extent able to predict the reactions of other possible interlocutors. According to this idea, Bakhtin/Volochínov ${ }^{22}$ (2014, p.116) states that "the word is addressed to an interlocutor: it is there in function of the person who is the interlocutor [...]" (highlighted by the author) ${ }^{23}$. Therefore, the writer repairs his or her own text after receiving his or her own feedback, after placing him or herself in the position of an interlocutor.

\section{Methodology}

This section is divided into two subsections. The first one is about the strategy we used to produce data for analysis in as authentic a manner as possible, so we could be in accordance with our theoretical bases. As it will be clear in the first subsection, what makes it authentic is the fact that the writers were students who were actually there in order to really learn how to produce opinion articles. The second subsection, in its turn, is about the computerized method we have used to identify and observe the phenomenon of repair by lexical synonymy in the data we produced.

\section{Authentic data production}

The production of the data analyzed in this study was carried out in the year of 2015, in the Research Laboratory entitled "Workshop of Reading, Writing and Rewriting of Opinion Articles" of the Pato Branco Campus of the Federal University of Technology of Paraná. The workshop aimed to teach undergraduate students how to write opinion articles. First time it was offered, in the first semester of 2015, the objective of the Workshop was to reduce difficulties in reading and writing by a group of undergraduates of the first term of the Letters Teacher Certification Program in Portuguese-English at the Pato Branco Campus. As a Research Laboratory, the Workshop also aimed to produce data for scientific studies like this one. Furthermore, the texts that were produced were intended to be published in the blog 'Pães $e$ Opiniães' (LIMA, 2016b), which was designed to function as a strategy of reaching out for real readership ${ }^{24}$. By means of the readers' comments in that digital platform, there is interaction of the writers with their target audience about their published opinion article.

The subjects who participated in this research produced, in total, six texts (AIOLFI; GÖTZ, 2016, p.1734-1735) throughout the workshop. This study focuses on the textual analysis of lexical synonymy of only the diagnostic text of one of these participants, a female student aged about 18 years old. The diagnostic text is the first text written, with only a little orientation from the professors. The only instructions

\footnotetext{
${ }^{21}$ Original: "[...] por sua vez, poderes diferentes de um leitor comum: é um leitor que é, ao mesmo tempo, o eu que escreve, que se lê, que se autocomenta, que reescreve, etc. Lebrave diz que escritura e leitura estão indissociavelmente intrincadas na produção do texto. O autor é mais leitor do que escritor. É sempre possível corrigir, modificar, anular, enriquecer o enunciado já produzido. Essas correções são mais efeito da leitura do que da escritura propriamente dita".

${ }^{22}$ The edition of Marxism and the Philosophy of Language consulted attributes the authorship of the work to Bakhtin/Volochínov. That is the reason why we credited the work with both names, although it was written by one of the authors Bakhtin/Volochínov.

${ }^{23}$ Original: "a palavra dirige-se a um interlocutor: ela é função da pessoa desse interlocutor [...]" (grifos do autor).

${ }^{24}$ The students knew that they were writing not only for themselves or for the teachers of the Workshop, but for real readers, external to the University, who would read their opinion articles and make comments. That was possible because the blog was open to anyone who wanted to read, counting on a space for comments at the end of the text.
} 
given were the following: the participants must write an opinion article (without specifying which would be the structure of the text) and must write about a present-day polemic topic.

The subsequent versions of the text were written based on more targeted orientations about the structure of the opinion article and about elements of textual construction. To our study, the diagnostic text is very important because, by using it we could analyze the students' beginning of the genre mastery development process.

It is important to point out that the Workshop was grounded in the principles of Dialogic Pedagogy. Lima and von Duyke (2016) make reflections about this educational approach based on the writings by Bakhtin. It is possible to establish a relationship between these authors' reflections and the work developed in the Workshop: the professors' approach in the Workshop leads to a process of development of the students' self-consciousness, thus guiding them throughout the process of writing and rewriting, by focusing on their inabilities, without eliminating their subjectivity. That is why the whole process matters, because the students' progress cannot be seen in a final version of a text.

Therefore, this perspective shows the authenticity of data production. The course of students' development is visible, happening while he or she was writing texts for other authentic purposes. All the pauses and hesitations are noticeable, and that is what makes the entire process of data production compatible with the research purpose.

\section{Computerized method: the use of AutoScreen Recorder and Inputlog}

Textual production was entirely carried out on the computers. This was so firstly because those computers are actually used at the university by teachers and their students for various educational purposes, and secondly, from the point of view of our research, because it was the most efficient way of recording writing processes in real time. Therefore, every student had his or her process of writing individually recorded. This recording took place by means of two softwares: AutoScreen Recorder and Inputlog (LEIJTEN; VAN WAES, 2013).

AutoScreen Recorder is a software that captures the computer screen, in a video recording everything that is done on screen. This functionality is used in the analysis of the data in order to monitor the text in its flow of production.

Inputlog (LEIJTEN; VAN WAES, 2013) is a program that executes some types of linguistic analyses over the process of textual files production. It has a connection with Microsoft Word, into which the text is typed. This tool records all the movements of the computer mouse and keyboard. The analyses used in this study, generated by the software, involve the recording of movements in intervals of one minute. The program generates reports in transcription symbols that represent the command executed in the computer. In this paper, we will present, analyze and discuss some excerpts of these reports. In order that the software language can be understood, we present below the meaning of each symbol of transcription that appears in the excerpts:

\begin{tabular}{|l|l|}
\hline Code & Meaning \\
\hline$[$ RSHIFT $]$ & Button 'caps lock' is pressed (indication of capital letter) \\
\hline. & Indication that the space bar was pressed \\
\{\} & $\begin{array}{l}\text { The pause, in seconds, is represented by the numbers that are between braces. Ex: } \\
\{10671\}-10 \text { seconds and 671 milliseconds }\end{array}$ \\
\hline
\end{tabular}




\begin{tabular}{|l|l|}
\hline & $\begin{array}{l}\text { There is indication of pause in cases where there are only five numbers between } \\
\text { braces. Cases in which more than five numbers appear can indicate selection of } \\
\text { characters or indication of deleted characters }\end{array}$ \\
\hline \{Movement\} & Any movement of the mouse \\
\hline [LEFT Click] & Click with the left button of the mouse \\
\hline [BACK] & Button 'backspace' is pressed (indication that characters are being erased to the left) \\
\hline$[$ RETURN] & Button 'enter' is pressed (indication of paragraph) \\
\hline$[$ OEM_7] & Buttons to the typing of stress characters are pressed (tilde and circumflex accent) \\
\hline$[$ OEM_4] & Buttons to the typing of the acute stress are pressed \\
\hline$[$ DELETE] & Button 'delete' is pressed (indication that characters are being erased to the right) \\
\hline$[$ Scroll] & Scrolling of the page with the mouse \\
\hline$[$ UP] & Button with the arrow $\uparrow$ (page up) is pressed \\
\hline$[$ INSERT] & Buttons to the typing of crase are pressed \\
\hline
\end{tabular}

Using the resources provided by the software, we started what we call the "mapping of repairs". With that mapping, we perceived various types of repairs that occurred in the text, among them the repair by synonymy. The mapping consists in the transcription of the text recorded in video concurrently with the analyses provided by Inputlog. Thus, we transcribe the text in its flow of production, including all the modifications made by the subject. This mapping was made following the chronological order of production, because by doing this we were able to determine the time of the beginning and end of each repair. Throughout the section of analysis in this paper, we will present the time at which each change took place, so that the order of writing of each word becomes clearer. ${ }^{25}$

This method is justified by the functions of both software. Without them, the phenomenon of repair by lexical synonymy would not be found and captured, because it happens only in the process of writing and rewriting, and does not appear in the final version of the text. The connection with Microsoft Word makes the writing process even more organic because students are familiarized with this text editing software. Inputlog and AutoScreen Recorder were run in the background, not being visible to the users of the text editor. Therefore, the possibility of control and regulation of writers' behavior because of the software simply does not exist. Therefore, we do not analyze machine-mediated discourse because what is recorded is actually the students' own discourse, without our interventions and, if any, with minimum interference. This approach is relevant because the students' discourse can be seen in its "natural" flow of production and their subjectivity is not at all erased from our study. On the contrary, it is revealed and shown more deeply in its complexity.

A limitation of the method is that we did not record the immediate extra-textual environment of production. For some long pauses, we hypothesized that the student writers could have been talking to each other or leaving the room. In addition, a microphone could have been used to record their conversation, and it would let us know if they were talking about their texts or about something else. Another limitation is that we cannot pinpoint where their focus actually was during production because we did not use an eye tracking method.

There is however no doubt that our methodology is connected and in accordance with the theoretical basis we previously outlined in section 1: by methodologically proceeding like we did, both in our Workshop (for data production) and in the use of the software (for data collection), we do not lose track,

\footnotetext{
25 The Inputlog generated three reports to the total time of recording (1h18min). The excerpts that will be presented belong to different reports and, because of this, there is discrepancy between the time indicated in the figures and the time when they really happened.
} 
for instance, of the idea of text as a dialogical process of communication, and not simply as a finished, motionless product.

The analyses that will be presented below were also supplemented and elaborated from informal conversations with the student who wrote the specific opinion article whose process of production we focus on. In these conversations, she briefly reported her motives of choice of each repair and the meaning difference she understands there is between one word and another. From her indications, we dialogically deepened the analyses of each word/repair.

We are not going to present analyses of all the changes that took place throughout 1 hour and 18 minutes of video length. We have chosen word changes we judge relevant to the argumentative process, because they were important to the comprehension of the writer's argumentation and because they allow the interpretation of the way she wanted to address her text to the target audience. The choice of terms reveals how the writer intended the readers to receive their text, how they would read it and how they would agree (or not) with the arguments. In other words, word choice reveals how the writer intended to respond to and potentially eliminate the presumed negative critiques and how she intended to get the readers to assent to her arguments.

The methods used to analyze and interpret the data are going to be the description of the repair in the flow of the text, followed by the meaning and the sense of the word in the text with some discussions grounded in previously presented theoretical basis. As it will be seen, the analyses were only possible by means of theoretical foundation, by which the phenomenon of repair by lexical synonymy can be explained.

\section{Findings and discussion}

The diagnostic text, in which the repairs by lexical synonymy were identified and analyzed, focused on the topic of violência no trânsito (traffic violence). The title chosen by the writer was Situação caótica que vive o povo brasileiro (The chaotic situation in which the Brazilian people live). The choice of the title shows her position: she considers traffic violence as something problematic in Brazil. Through the recordings, we detected that the title was written after the text was finished. This way, the textual choices of the writer preceded the title, which had the function of summarizing the written idea.

To make clearer the context in which the analyzed excerpts took place, we present below the final diagnostic text written by the writer ${ }^{26}$. The repairs will be presented in the ascending order according to the lines where they happened.

\section{Lines Chaotic situation in which Brazilian people live}

1 Thousands of traffic accidents happen everyday all around the world. In Brazil, 60

2 thousand deaths were caused last year, according to data from the World Health

3 Organization (WHO). It frightens me to know that most part of these deaths happen to

4 youngsters, from 18 to 29 years of age, that act many times with irresponsibility.

5 In some countries, such as Germany, the number of accidents and deaths in traffic

6 was considerably reduced. However for this to occur the government needed to be more

7 strict, creating laws with more severe punishments, as well as the population doing its

8 part. In Brazil, I believe that this is the biggest problem. The laws somehow do not punish

9 those responsible for causing accidents with deaths, and the population seems not to care

${ }^{26}$ The original text written by the writer in Brazilian Portuguese is attached in the end of this paper. The text was transcribed exactly as it was written in its final version handed in for evaluation. 
10 about the absurd number of deaths that occur annually.

11 It is inadmissible to accept that so many lives are lost. Today in Brazil it is perceptible

12 that greatest number of deaths is considered by the Brazilian justice as manslaughter, in

13 which there is not the intention to kill. Cases like this serve as a encouragement to many

14 drivers who act irresponsibly, so they can get rid of the real punishment that they deserve,

15 being up to them as sentence the donation of some baskets of basic food supplies, and to

16 help in community service. ${ }^{27}$ This should not be allowed to happen, not even thousands

17 of baskets of basic food supplies could pay for the value of a human life.

18 We need to take some action. It is unacceptable that I, who am a driver, cyclist and

19 pedestrian take a risk of not going back home safely everyday. To give an idea, I need to

20 fear more the mister or the youngster who is driving a car than to fear the possibility of

21 having a tumor, because it is proven that traffic accidents kill more than cancer.

22 Measures need to be taken with urgency, because the number of deaths that we see in 23 the statistics points to a very serious problem. The average Brazilian either does not know

24 how to drive or is not being well instructed for this. I refuse to accept that there exists

25 the possibility that someone can do wrong out of pure irresponsibility, I rather believe

26 that there is a lack of knowledge and a lack of information. For this reason, the driving

27 schools have a fundamental role in the process of decreasing the accidents. They must

28 make drivers have their licenses renewed more frequently, and not each 5 years as it

29 occurs nowadays.

30 The public authorities also need to improve the traffic engineering, since the Brazilian

31 roads are in a chaotic situation, facilitating the occurrence of tragedies. "Awareness

32 campaigns" must occur more frequently through public bodies, seeing that in my city

33 awareness campaigns are made only in the "traffic week". Maybe, continuous

34 information will help the driver to realize how important responsible action is.

35 The War of Canudos ${ }^{28}$ killed 30 thousand people in Bahia's hinterland. We live a war that has the same proportions twice every year, but in the traffic. It is necessary to fight against this war so the victims will not exist anymore, for this to occur everybody must be aware. When it has an end, the biggest and the better award will be received, life.

\section{Pessoas ou jovens? (People or youngsters?)}

The first change that will be analyzed happens at the sixth minute of recording, in the excerpt corresponding to lines 3 to 4 of the diagnostic text.

${ }^{27}$ In Brazil, in some sentences, the judge of the court decides that the convicted person, instead of being arrested, should donate basic food supplies to needy people. There is another type of sentence in which the judge decides that the convict should do community work.

28 The War of Canudos happened between 1896 and 1897 involving federal government troops against settlers led by a religious leader named Antonio Vicente Mendes Maciel, known as Antonio Conselheiro (1828-1897). He preached a mix of Christian doctrine with popular religiosity and founded the village called Canudos. In Canudos he created a movement that criticized the Republic. The War started when the villagers protested against the charge of taxes and ended with the end of the village, with over 30,000 deaths. 


\begin{abstract}
00:05:00
[RSHIFT]([RSHIFT]OMS). $\{10671\}$ [Movement][LEFT Click][LEFT Click][Movement][LEFT Click][LEFT Click][Movement][LEFT Click][LEFT Click][Movement][LEFT Click]

[Movement][LEFT Click][Movement]-[RSHIFT]Destas -mortes, $\cdot\{2044\}$ assusta-me-asab [BACK][BACK][BACK][BACK] saber-que-a-grande[Movement][LEFT Click][Movement] [BACK][RSHIFT] $\{18446744073709551304\}$ A[BACK] [RSHIFT][RETURN]Ass[BACK] [BACK][BACK][BACK][RSHIFT]Assust

00:06:00

ame-[BACK][BACK][BACK][BACK]a[Movement][LEFT Click][Movement] $\{2091\}$ maioria -dessas-mortes-\{4992\}s[OEM_7]ao-com pessoas BACK][BACK][BACK][BACK][BACK] [BACK] [BACK] [BACK] 1ovens [BACK], de -18-[RSHIFT][OEM_4] a-24-aos.[BACK][BACK] [BACK]n-[BACK] os. $\{4539\}[B A C K], \cdot[B A C K][B A C K][B A C K][B A C K][B A C K][B A C K][B A C K]$ [BACK] 9-anos-[BACK], -que-muito[BACK]as-vezer[BACK]s[Movement][LEFT Click] [Movement][Movement][TAB][Movement][LEFT Click] $\{6630\}$

$00: 07: 00$

[Movement] 2387$\}$ [Movement][LEFT Click][Movement][DELETE][DELETE] \{2013\} [BACK] $\{3088\}$ acontecem $\{4820\}$ [Movement][LEFT Click][Movement][LEFT Click] [Movement]-agem-com-irresponsabilidade. $\{14243\}$ [RETURN][Movement][LEFT Click] [Movement] $\{2200\}[$ Movement] $\{16661\}$
\end{abstract}

Figure 1 Transcription provided by Inputlog

The first choice, pessoas (people), was replaced by jovens (youngsters) almost immediately. Through the transcription provided by Inputlog, presented in figure 1, we notice that there was not a pause between the writing of pessoas (people) and the change to jovens (youngsters).

Pessoas (people) and jovens (youngsters) are not perfect synonyms, because they do not necessarily express the same idea. The first one refers to human beings, in general, that, in this context, can drive. The second one refers to the specific age group of the drivers, from 18 to 29 years old, who are considered young by the writer. In other words, pessoas (people) does not necessarily have the trait of jovens (youngsters), while jovens (youngsters) necessarily has the trait of pessoas (people).

The change can be justified by the target audience of the opinion article. The writer previously knew that her text would be published in a blog and that this one would be promoted, among other audiences, to the academic community, composed, in its majority, by people of the mentioned age group. Besides, the argument chosen to validate her opinion is related to specific statistics about the age of those involved in traffic accidents. In other words, the choice of argument may have influenced the choice of word. On the other hand, the intention to write a text about the young population may have influenced the option for the chosen argument. Another reason that may have interfered in the selection of the word were the contents studied throughout her school life. As it has previously been pointed out, the undergraduate writer is part of a group of students of the first term of a Teaching Degree in Letters. Before entering college, she took ENEM (Exame Nacional do Ensino Médio - National High School Exam) and its essay test. One of the instructions for the essay is that students should avoid straying away from the topic, which happens when the subject of the text is not developed (INEP, 2016, p.15). When the writer used the expression pessoas (people), the idea of generalization and of straying away from the argument may have occurred, compromising the development of the text. Using jovens (youngsters), she limits the sample of the argument and directs the reading of the text.

The substitution of people (pessoas) with youngsters (jovens) was chosen to be analyzed here as a repair because it was important to the process of argumentation. By means of her final choice, the writer shows her concern about adequate choice of a word (pessoas/jovens) in addressing an assumed interlocutor (BAKHTIN/VOLOCHÍNOV, 2014, p.116). She also shows her concern in regard of the word serving the aims of her argumentation (PERELMAN; OLBRECHTS-TYTECA, 2005, p.04), by guiding her argument and by directing the reading of her interlocutor. Moreover, she shows knowledge about certain 
aspects of the genre (BAKHTIN, 2011, p.263), by avoiding straying away from the topic, an instruction that fits the essay of ENEM, another kind of argumentative text that she has already written.

\section{Câncer ou tumor? (Cancer or tumor?)}

In this repair, which occurred at the fifty-second minute of the recording and which is presented in line 23-24, the writer used euphemism to employ synonyms due to their argumentative potential.

\begin{tabular}{|c|c|}
\hline $00: 14: 00$ & 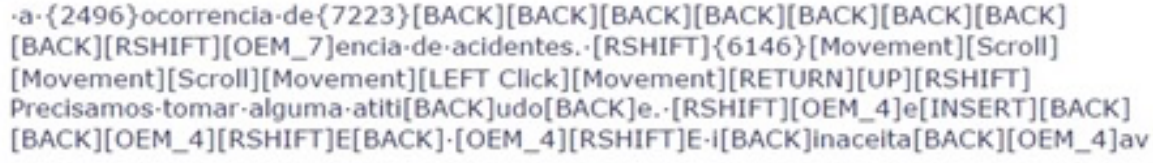 \\
\hline $00: 15: 00$ & 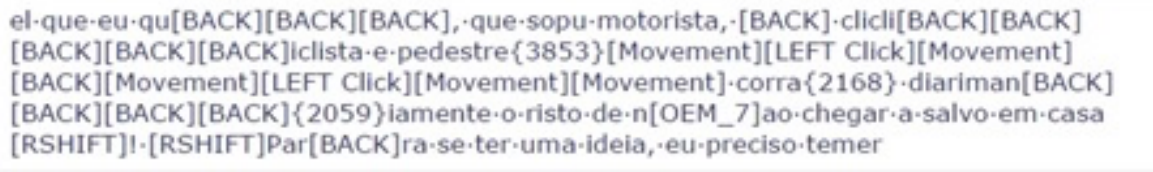 \\
\hline $00: 16: 00$ & 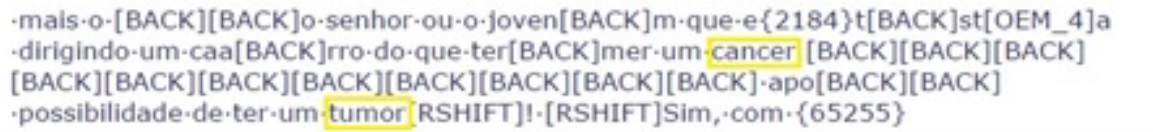 \\
\hline
\end{tabular}

Figure 2 Transcription provided by Inputlog

Câncer (cancer) was the first typed word, being right after that substituted by tumor (tumor). Here occurs something remarkable related to the meaning of the words. A tumor is a tissue without physiological function that proliferates itself abnormally, and a cancer is a malignant tumor (MICHAELIS, 2008, p.156, p.886).

According to the meaning of the words, both of them are related to tumors, but the word câncer (cancer), as well as its meaning, has a much bigger negative semantic load in speech. In the context in which the word was written, we understand that tumor (tumor) carries more of a positive connotation than câncer (cancer), which carries a negative connotation. In other words, the word was not employed in a neutral way.

The motivation for the use of a milder word is shown in the sequence of the text. In line 25 the word câncer (cancer) is used again. If we consider the load that the word câncer (cancer) carries to speech, it is possible to think of the load that the writer took in consideration when writing. Starting with the word with a soft tone, in a certain way, the effect of worsening of the situation is detected when we read the word with a more impacting tone. Therefore, there is a growing significance, from the softer to the more contentious tone. There is a gradation of the argumentative force.

The heritage from school knowledge is also perceptible in this change. When the writer chose not to repeat the same word twice, she is avoiding repetition, which is a recommendation given by teachers regarding all kinds of essays (situations in which repetition becomes a stylistic effect are exception), including the essay for ENEM (INEP, 2016, p.18).

The choice of analyzing this specific repair is justified because it shows a lot about the argumentative consciousness that the writer had when executing the substitution for a softer word instead of a more polemic one at a first moment. She sought a word that could be more appropriate to her argumentative objective (LIMA, 2016a, p.29; PERELMAN; OLBRECHTS-TYTECA, 2005, p.04), that is, in 
this case, to create a growing significance that could be more appealing to her interlocutor. This was important in order for her to position herself in relation to her topic. By claiming that the situation with traffic is as dangerous as a tumor or a cancer, she guides the reader through her text. Furthermore, the meaning load of "cancer" seems to be a very important argumentative point, because even if it is not the triumphant word (VIGOTSKI, 1996, p.67), she did not leave it out of her text, because the word was repeated later.

\section{Cobrar, exigir ou fazer com que? (To require, to demand or to make somebody have something done?)}

This change of synonyms begins at the forty-sixth minute, in line 32.

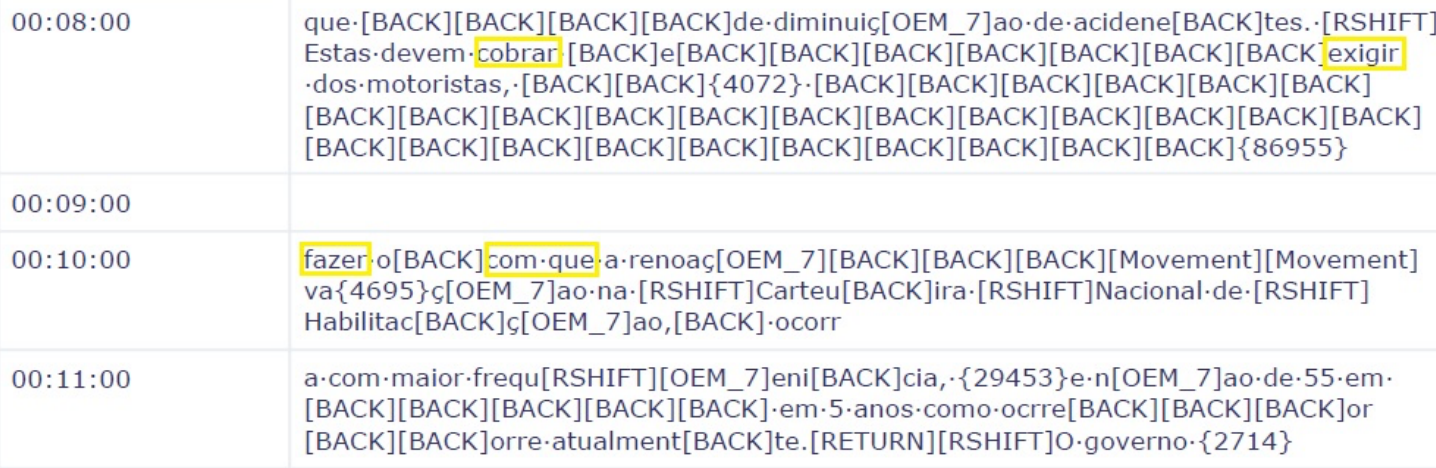

Figure 3 Transcription provided by Inputlog

In the substitution of cobrar (to require) for exigir (to demand) there was only a very short pause, but in the replacement of exigir (to demand) for fazer com que (to make somebody have something done) there was approximately one minute and twenty-nine seconds of pause. This time was probably dedicated to the rereading of the text or maybe to some extra-textual activity that deviated her from her writing activity.

This pause explains the writer's hesitation in view of her available choices to adjust her opinion to the text: the argumentative potentials of the words available were in conflict (VIGOTSKI, 1996, p.67). The verb cobrar (to require) has the meaning of receiving something that is due, of forcing the charge of something (MICHAELIS, 2007, p.195) often related to monetary quantities. Then its substitution for the verb exigir (to demand) was quick, in the effort of eliminating the monetary and colloquial meaning of the word. Exigir (to demand), in this context, would have the formal meaning of imposing something as a duty (MICHAELIS, 2008, p.376). Exigir (to demand) would have a more practical meaning than cobrar (to require). However, right after the excerpt "exigir dos motoristas" (to demand from drivers) was written, it was soon deleted. When the pause of one minute and twenty-nine seconds happened, the writer could read her text and analyze which changes would be relevant to provoke a certain reaction in the reader. By choosing the expression fazer com que (to make somebody have something done), she puts the obligation on the driving schools, the undeniable duty of executing their role in drivers' education. Fazer com que (to make somebody have something done) shows an action even more practical than exigir (to demand) because it gives the idea that some attitude will be taken and not just the solicitation that some requirements are met. In the argumentative scheme of the text, we can assume that the writer uses this term to, again, solicit an agreement from the target audience.

Our analysis of this repair was based on the dictionary meaning of the words because, even if they are slightly similar, their meanings are not perfectly the same (PIETROFORTE; LOPES, 2008, p.126). 
Context was crucial here (ILARI; GERALDI, 2006, p.44-46), because it determined the sense of the words in the text. The pauses show that she hesitated and oscillated between her possible choices and that she was trying to adapt the word to the sentence (LIMA, 2016, p.24) and to the idea defended in the sentence. Again, she probably had the target audience in her mind, making efforts to comply with the specificities of the text.

\section{Governo ou poder público? (Government or public authorities?)}

This repair starts at the forty-ninth minute of recording, in line 34.

The word governo (government) was replaced by poder público (public authorities) approximately thirty seconds after it was written. In this interval, the writer wrote O governo ao (The government when), deleted ao (when), wrote ta, which we believe to be the beginning of the word também (also), saved and renamed the file in the computer.

\begin{tabular}{|c|c|}
\hline $00: 11: 00$ & 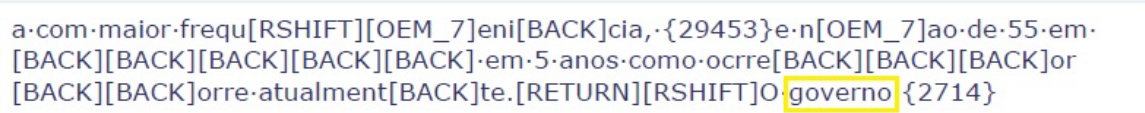 \\
\hline $00: 12: 00$ & 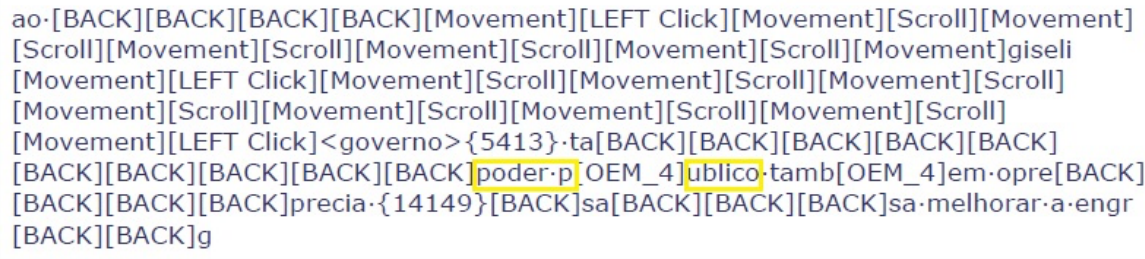 \\
\hline $00: 13: 00$ & 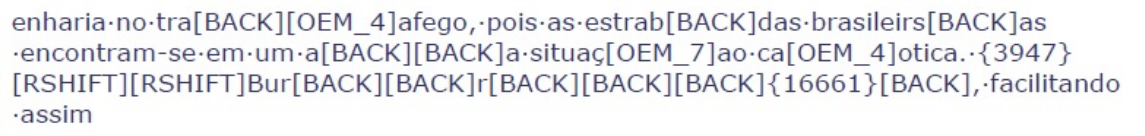 \\
\hline $00: 14: 00$ & 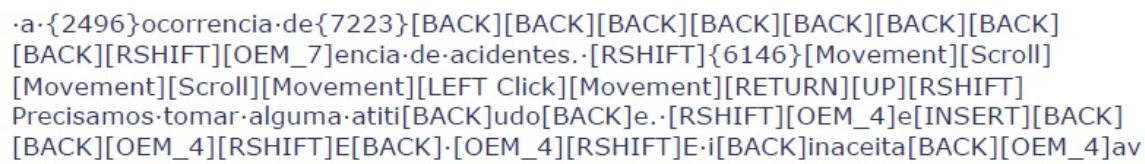 \\
\hline
\end{tabular}

Figure 4 Transcription provided by Inputlog

Those terms are not perfect synonyms (PIETROFORTE; LOPES, 2008, p.126) and, despite being very close as far as their meaning in the text is concerned, we can infer some differences between them. Governo (government) can have the meaning of current management, which could infer partisanship. Poder público (public authorities) can have a wider meaning, covering all the governments that had already managed and all the others that will manage the country. We can also infer that governo (government) regards only the Executive Power of the country (SILVA, 2014, p.1013), while poder público (public authorities) can cover the Executive, Legislative and Judicial Powers (SILVA, 2014, p.1600). Moreover, governo (government) can sound cliché in comparison to poder público (public authorities), which may suggest a larger vocabulary repertoire coming from the writer.

According to the possible constructed meanings, we can now talk about the possible motivations of the writer to opt for poder público (public authorities). The text was written in April of 2015, a period in which the state-owned company Petrobras was going through a turbulent phase (UOL, 2015). The issue was in its apex of discussion and, potentially to avoid touching on political party matters, she avoided the word governo (government) because this one could refer to the party that was managing the country, even 
if the subject of her text did not directly relate to that theme. By using poder público (public authorities), the writer keeps herself out of that political discussion and still distributes the responsibility, somehow, among the three governmental branches. ${ }^{29}$ This is related to the the author's motive to get an acceptance of the text by the target audience. If she had defended any political party, the text (and the writer herself) could have been attacked by the readers, who, depending on the political point of view defended, could offer resistance to the opinion she defended. In an informal conversation with the writer, she expressed her concern about her readers moving away from her opinion because of lexical choices. Thus, she thought that if the final word had been governo (government), this could have happened. That is why this specific repair was brought to this paper to be analyzed: because the context that is connected to the choice of a word is not merely the context of a sentence, but also the one in which the writer is thrown in her actual life.

In this repair, she chooses a term that would not seem to be advocating a political party issue, but rather a call for the general responsibility of the State. Thus, poder público (public authorities) can be more convincing and can make a larger number of readers accept the defended point of view.

\section{Acidentes ou tragédias? (Accidents or tragedies?)}

This repair starts at the fiftieth minute of recording, in line 36

\begin{tabular}{|c|c|}
\hline $00: 14: 00$ & 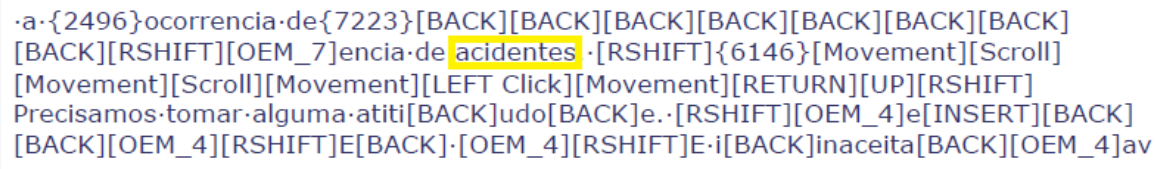 \\
\hline $00: 21: 00$ & $\begin{array}{l}\text { [Movement][LEFT Click][Movement][DELETE][BACK][BACK][DELETE] traj OEM_4]e } \\
{[\text { BACK][BACK][BACK][BACK][BACK] }\{20858\} \text { trag[OEM_4 edias Movement][LEFT Click] }} \\
{[\text { Movement][LEFT Click][Movement] }\{7675\}[\text { RSHIFT }]\{26115\}}\end{array}$ \\
\hline
\end{tabular}

Figure 5 Transcription provided by Inputlog

The writer typed the word acidentes (accidents) at the fiftieth minute of the production and right after that started writing another paragraph, before this one, without discarding the part that had been already written. Seven minutes passed while she wrote the new part and an additional twenty-seven seconds after $^{30}$ the end of the new paragraph she substituted acidentes (accidents) for tragédias (tragedies).

According to the context, acidentes (accidents) can be understood as any unpleasant happening in traffic. Tragédias (tragedies), however, refer to the idea of fatality, of something irremediable. Acidente (accident) is a disgrace, an unplanned disaster (MICHAELIS, 2008, p.13). Tragédia (tragedy) is a "sad catastrophic happening"31 (MICHALIS, 2008, p.870). A catastrophic happening is a situation that "has the proportions of catastrophe"32, which can be conceptualized as a "huge disaster; public sacrifice" 33 (MICHAELIS, 2008, p.172). Thus, the idea of tragédias (tragedies) refers to happenings that cause deaths, having a character of more negative impact than the one of acidentes (accidents).

\footnotetext{
${ }^{29}$ At the time that this opinion article was written, there was a major conflict between voters of the left and right parties. Using the term governo (government) would take the reader straight to the presidency of the republic, unlike poder público (public authorities), which includes the three branches of power, whose representatives stand for different parties.

${ }^{30}$ Through the recording in video, we verified that all the movements between the typing of acidentes (accidents) and the beginning of the typing of tragédias (tragedies) took, approximately, $7 \mathrm{~min} 27 \mathrm{~s}$ to be concluded.

31 Original: "acontecimento triste, catastrófico".

32 Original: "assume proporções de catástrofe".

${ }^{33}$ Original: "grande desgraça; hecatombe".
} 
Here we can highlight the urgency of her appeal to stay with her argument, addressed to the target audience, as was proposed by Perelman and Olbrechts-Tyteca (2005). We can realize the sensationalist and appealing character of the term tragédias (tragedies) in comparison to the term acidentes (accidents). Bringing an expression that represents the chaotic dimension of Brazilian traffic, she may convince a larger number of people to adhere or to agree with her opinion.

In the twenty-seven seconds of pause, she was probably rereading the text that had been already written. Thus, the writer became at this point, as in many others, her first reader, as it was pointed out by Grésillon and Lebrave (1983 apud SALLES, 2008). Predicting some kind of resistance from other readers, in other words, anticipating a possible utterance of negative criticism, she revisits her first position and repairs her text while thinking about her interlocutor, as indicated by Bakhtin/Volochínov (2014). Thereby, the new word, tragédias (tragedies), brings back the focus on the fatality of traffic accidents to the text.

\section{Pois ou visto que? (Because or seeing that?)}

The last change of synonyms to be analyzed in this paper occurs at the sixty-first minute of the textual production, in line 37.

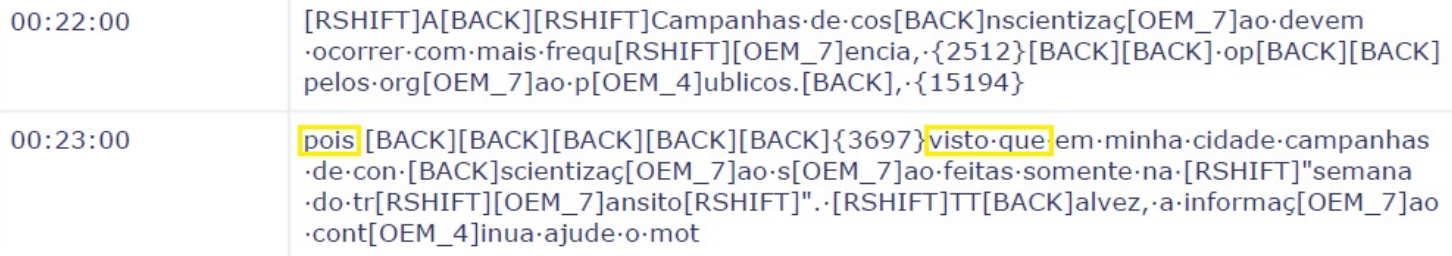

Figure 6 Transcription provided by Inputlog

As soon as the word pois (because) was written, it was right after substituted for visto que (seeing that). In this repair it does not seem that there were motivations related to the grammatical classification of the word, since pois (because) is almost an exact synonym of visto que (seeing that) in this case. Both of them are subordinating conjunctions that present the meaning of relating two sentences with the indication of justification of the first by the second (CUNHA; CINTRA, 2013, p.595).

Nonetheless, pois (because) sets up just as a conjunction and it has the function of relating two sentences. Visto que (seeing that), in addition to the function of conjunction, has the verb ver (to see) conjugated in the present continuous ${ }^{34}$. A person who "has seen" something tends to believe it more, because he or she is an eyewitness of the situation. Thus, there is a semantic trait in visto que (seeing that) that is not present in pois (because), and this trait causes visto que (seeing that) to have a stronger argumentative force.

In addition, something that relates to the "moral character"35, to the ethos of the writer (PLATIN, 2008, p.112) takes place at this point. By using visto que (seeing that), she searches for a more sophisticated vocabulary, in order to bestow authority to her speech. In the attempt of representing herself as someone who masters a vast vocabulary, the writer substituted a less formal pois (because), with a

\footnotetext{
${ }^{34}$ In Portuguese this verb is in fact in the past participle.

${ }^{35}$ Original: "caráter moral".
} 
more formal visto que (seeing that). Plantin (2008, p.112) highlights a constitutive element of ethos as something "of the order of reputation, prestige, even charisma" 36 in the argumentative authority.

This repair was chosen for analysis because the writer said that visto que (seeing that) was "fancier" than pois (because). The impact of a "fancier" word on the interlocutor would be more penetrating, according to the writer. This shows the level of her awareness of the social specificities of the genre (LIMA, 2016a, p.24), in which she was supposed to impress her reader in order to be persuasive.

As the final choice is a more formal word, the reader can make inferences about the writer's character: in this case, she would be someone believable because she masters a sophisticated vocabulary. Therefore, the writer's image would be manifested in her speech as well as the readers' commitment, since it imparts to both of them the condition of eyewitnesses of those who "have seen".

\section{Final Remarks}

In this article, based on theories of Linguistics and Psychology, we have sought to identify and analyze dialogic functions of repair by lexical synonymy in the process of writing and rewriting an opinion article.

Our major findings answer to our initial research question: What are the dialogic functions of repair by lexical synonymy in the process of writing and rewriting of an opinion article? The dialogical functions found relate primarily 1 ) to the addressivity in a text; 2 ) to textual adjustments; 3 ) to the content of discourse; and 4) to the work of construction of the writer's image. In some way, all the repairs are motivated by the writer's assumptions about the reception of the text by the target audience. This idea is compatible with Bakhtin/Volochínov's idea (2014, p.116) about aiming the discourse at an interlocutor. The hesitations of the writer are therefore of social, dialogic and argumentative nature (LIMA, 2016a, p.27).

This study is important, among other reasons, because of the methodology used to gather the data, since the software was used in a way that did not seem to interfere with the normal flow of the writer's production, therefore keeping it as authentic as possible. As it was mentioned before, technical limitations prevented us from collecting data related to the immediate extra-textual environment in the process of writing. However, integrating pedagogical and computerized methods (the Workshop and the use of software) provides a wide range of possibilities to the field of Linguistics, Psychology and Education. In addition, this methodology shows a way of using technology in studying dialogic aspects of writing, through having access to the process of writing that helps in reconstructing the writer's path to her final choices, thereby partly revealing her motivations. In addition, our perspective presents a different way of analyzing data, different from the analysis of erasures (SALLES, 2008) and the analysis of conversation (SCHEGLOFF, 1979). An online research did not reveal other works about repair in written production, making our study a unique contribution to procedural studies.

The implications for understanding repair by lexical synonymy are in accordance with the perspective in the work of Vygotsky (VIGOTSKI, 2007, p.63). By analyzing one of the constitutive points of the process of writing, it is possible to understand the function and the development of other points of the textual production process. Research that studies phenomena in their flow of happening can be great contributions to our fields. Due to the procedural characteristic of our studies, this one specifically presents

\footnotetext{
${ }^{36}$ Original: "da ordem da reputação, do prestígio, até mesmo do carisma".
} 
future possibilities of expansion: in order to indirectly access more of the motivations of writer's choices, we intend to use it in the future work.

Thus, repair by lexical synonymy proves to be a very rich textual strategy that can be taught to help developing writers, as much as possible, to reach their greater objective, which is to get the readers to a stronger agreement with their position.

\section{References}

AIOLFI, G. P. A. GÖTZ, G. Aprender a argumentar para aprender a ensinar a argumentação: relato de experiência com o gênero "artigo de opinião". In: III Seminário Internacional de Estudos sobre Discurso e Argumentação, 3, São Cristóvão. Anais do III Seminário Internacional de Estudos Sobre Discurso e Argumentação. Ilhéus: Editus, 2016, p.1732-1742. Available at: [http://octeventos.com/site/sediar/anais.php] Date accessed: 06 Jul. 2017.

AL-HINDAWI, F. ALKHAZAALI, M. A. A stylistic study of synonymy in W. Wordsworth's poetry. اداب الكوفة, [S.I.], v. 1, n. 18, apr. 2014. Available at: [http://www.uokufa.edu.iq/journals/index.php/kufa_arts/article/view/2536]. Date accessed: 13 Aug. 2018.

BAKHTIN, M. Os gêneros do discurso. In.: BAKHTIN, M. Estética da criação verbal. 6.ed. Trad. Paulo Bezerra. São Paulo: Martins Fontes, 2011, p.261-306.

BAKHTIN, M. (VOLOCHÍNOV). Marxismo e filosofia da linguagem: Problemas fundamentais do método sociológico da linguagem. 16.ed. Trad. Michel Lahud e Yara Frateschi Vieira. São Paulo: Hucitec, 2014.

BIASI, Pierre-Marc. O Horizonte Genético. In: ZULAR, Roberto. (Org.). Criação em processo - Ensaios de crítica genética. São Paulo: lluminuras, 2002. p. 219-252.

BOFF, O. M. B.; KÖCHE, V. S.; MARINELLO, A. F. O gênero textual artigo de opinião: um meio de interação. ReVEL, vol. 7, n. 13, p.1-12, 2009. Available at:

[http://www.revel.inf.br/files/artigos/revel_13_o_genero_textual_artigo_de_opiniao.pdf] Date accessed: 07 Sep. 2016.

CHAFE, W. L. Linguistic differences produced by differences between speaking and writing. In: OLSON, D. R.; TORRENCE, N.; HILDYARD, A. (Eds.). Literacy language, and learning: The nature and consequences of reading and writing. Cambridge: Cambridge University Press, 1985, (p. 105123).

CLARK, E. V. ANDERSEN, E. S. Spontaneous Repairs: Awareness in the Process of Acquiring Language. Papers and Reports on Child Language Development. n. 16. p. 01-12. jan. 1979.

CUNHA, C. CINTRA, L. Gramática do português contemporâneo. 6.ed. Rio de Janeiro: Lexikon, 2013.

GRÉSILLON, A. LEBRAVE, J. L. Avant propos. Langages, n.69, p. 05-10, 1983. Available at: [http://www.persee.fr/doc/lgge_0458-726x_1983_num_17_69_1138] Date accessed: 06 Jul. 2017.

HAY, Louis. L'écriture vive. Préface. In: HAY, Louis. (Org.). Les manuscrits des écrivains. Paris: CNRS Éditions/ Hachette, 1993. p. 10-33.

ILARI, R. GERALDI, J. W. Semântica. 11.ed. São Paulo: Ática, 2006. 
INSTITUTO NACIONAL DE ESTUDOS E PESQUISAS EDUCACIONAIS ANÍSIO TEIXEIRA. A redação no ENEM 2013: Guia do participante. Brasília, 2013. Available at:

[http://download.inep.gov.br/educacao_basica/enem/guia_participante/2013/guia_de_redacao_en em_2013.pdf]. Date accessed: 18 Jul. 2016.

LEIJTEN, M.; VAN WAES, L. Keystroke logging in writing research: using Inputlog to analyze and visualize writing processes. Written Communication, v.3, n.30, p. 358-392, 2013.

LIMA, A. Dialogism, argumentation and human development: an approach to teacher professional gestures by means of the self-confrontation method. Bakhtiniana, v. 8, n.1, 2013. Available at: <http://revistas.pucsp.br/index.php/bakhtiniana/article/view/12830/11694>. Date accessed: 05/27/2019.

LIMA, A. Procedimentos teórico-metodológicos de estudo de gêneros do discurso: atividade e oralidade em foco. In: BRAIT, B. MAGALHÃES, A. S. (Orgs.) Dialogismo: teoria e $(\mathrm{m})$ prática. São Paulo: Terracota, 2014. p.37-53.

LIMA, A. Inarticulateness as a developmental process from inability to ability in speech genres. Language Sciences, v.53, p.-21-30, 2016a.

LIMA, A. Blog Pães e Opiniães. 2016b. Available at: [http://paeseopiniaes.blogspot.com.br/] Date accessed: 05 Jan. 2017.

LIMA, A. VON DUYKE, K. Reflections on a dialogic pedagogy inspired by the writings of Bakhtin: an account of the experience of two professors working together in the classroom. Dialogic Pedagogy: An International Online Journal. v.4, p.A98-A121, 2016. Available at: [https://dpj.pitt.edu/ojs/index.php/dpj1/article/view/159] Date accessed: 12 Aug. 2018.

MICHAELIS. Dicionário prático da língua portuguesa. São Paulo: Melhoramentos, 2008.

PERELMAN, C. OLBRECHTS-TYTECA, L. Tratado da argumentação: a nova retórica. 2.ed. São Paulo: Martins Fontes, 2005.

PIETROFORTE, A. V. S. LOPES, I. C. Semântica Lexical. In: FIORIN, J. L. Introdução à linguística II: princípios de análise. 4.ed. São Paulo: Contexto, 2008. p.111-135.

PLANTIN, C. A argumentação. São Paulo: Parábola, 2008.

RODRIGUES, Â. C. S. Língua falada e língua escrita. In: PRETI, D. (Org). Análise de textos orais. 7. ed. São Paulo: Humanitas, 2010. p. 15-37.

SALLES, C. A. Crítica genética: fundamentos dos estudos genéticos sobre o processo de criação artística. 3. ed. São Paulo: EDUC, 2008.

SCHEGLOFF, E. The Relevance of Repair to Syntax-for-Conversation. Syntax and Semantics. v. 12. p. 261-286. 1979.

SCHEGLOFF, E. JEFFERSON, G. SACKS, H. The Preference for Self-Correction in the Organization of Repair in Conversation. Language, v.53, n.2, jun., 1977, p. 361-382 Available in: [https://www.jstor.org/stable/413107] Date accessed: 06 Aug. 2018.

SILVA, D. P. Vocabulário Jurídico. Atualizadores: Nagib Slaibi Filho e Priscila Pereira Vasques Gomes. 31. ed. Rio de Janeiro: Forense, 2014.

SILVA, A. S. Competition of synonyms through time: Conceptual and social salience factors and their interrelations. Catalan Journal of Linguistics, [S.I.], v. 14, p. 199-218, dec. 2015. Available at: [https://revistes.uab.cat/catJL/article/view/v14-soares]. Date accessed: 13 Aug. 2018. 
SILVA, M. I. L. E. Crítica Genética na era digital: o processo continua. Letras de Hoje, Porto Alegre, v. 45, n. 4, p. 43-47, out./dez. 2010.

SPÁČILOVÁ, G. On Collocational Restrictions (A Case Study). Bachelor's thesis. Masaryk University, Faculty of Arts. Thesis supervisor doc. PhDr. Naděžda Kudrnáčová, CSc. 2009. Available at: [https://theses.cz/id/5tdwdx/]. Date accessed: 13 Aug. 2018.

STANOJEVIC, M. Cognitive Synonymy: A General Overview. Facta Universitatis. v. 7. n. 2. p.193-200. 2009.

UOL. Quer entender o que acontece na Petrobras? Veja este resumo. Available at: [http://economia.uol.com.br/noticias/redacao/2015/02/05/quer-entender-o-que-acontece-napetrobras-veja-este-resumo.htm] Date accessed: 10 Sep. 2016.

VIGOTSKI, L. S. A consciência como problema da psicologia do comportamento. In: Teoria e método em psicologia. Trad. Cláudia Berliner. São Paulo: Martins Fontes, 1996. p.55-85.

VIGOTSKI, L. S. A formação social da mente: o desenvolvimento dos processos psicológicos superiores. 7.ed. São Paulo: Martins Fontes, 2007.

WACHOWICZ, T. C. Análise linguística nos gêneros textuais. São Paulo: Saraiva, 2012.

\section{(cc) EY}

New articles in this journal are licensed under a Creative Commons Attribution 4.0 United States License.

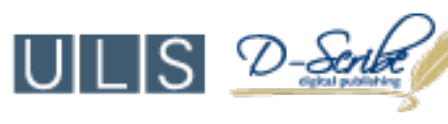

This journal is published by the University Library System, University of Pittsburgh as part of its D-Scribe Digital Publishing Program and is cosponsored by the University of Pittsburgh Press. 